Middle School Students' Opinions Regarding Their Educational Experience during Covid-19 Pandemic

Alexandra Ioana Oltean 


\title{
Middle School Students' Opinions Regarding Their Educational Experience during Covid-19 Pandemic
}

\author{
Alexandra Ioana Oltean ${ }^{a^{*}}$ \\ ${ }^{a}$ Babeș-Bolyai University, Faculty of Psychology and Educational Sciences, 7 Sindicatelor Street, Cluj-Napoca, 400029, Romania \\ *Corresponding author: alexandra.bolboaca@ubbcluj.ro
}

\section{Abstract}

\section{Keywords:}

Covid-19 Pandemic; online education; students' opinions
The Covid-19 Pandemic has affected everyone's life. The main activity fields of each society were strongly impacted by the different measures imposed by authorities in order to limit and prevent the extension of this new disease. Students are one of the vulnerable categories, influenced significantly by this situation since one of the social distancing measures implemented in most countries refers to school closure and classes suspension. The transition to online education undertaken in this context was a temporary solution, a quick fix, and its long-term implications need to be studied within further research. We asked a small group of middle school students to share their thoughts, feelings and opinions regarding their educational experiences during the pandemic. Students shared valuable aspects that need to be taken into consideration in order to optimize future distance learning approaches, but also the ones specific to traditional education. Rethinking education has become one of the major present goals, since education has profound, long-term implications over all other fields of the society.

\section{Zusammenfasung}

\section{Schlüsselworte:}

Covid19 Pandemie;

Online-Bildung;

Studenten Meinungen
Die Covid-19-Pandemie hat das Leben aller Menschen beeinflusst. Die Haupttätigkeitsbereiche jeder Gesellschaft waren stark von den verschiedenen Maßnahmen der Behörden betroffen, um die Ausweitung dieser neuen Krankheit zu begrenzen und zu verhindern. Die Studenten sind eine der gefährdeten Personengruppen, maßgeblich beeinflusst durch diese Situation, da sich eine der in den meisten Ländern umgesetzten Maßnahmen zur sozialen Distanzierung auf die Schließung von Schulen und die Suspendierung von Klassen bezieht. Der Übergang zur Online-Bildung in diesem Zusammenhang unternommen war eine vorübergehende Lösung, eine schnelle Lösung, und ihre langfristigen Auswirkungen müssen im Rahmen weiterer Forschungen untersucht werden. Wir haben eine kleine Gruppe von Mittelschülern gebeten, ihre Gedanken, Gefühle und Meinungen zu ihren Bildungserfahrungen während der Pandemie mitzuteilen. Die Schüler teilten wertvolle Aspekte, die berücksichtigt werden müssen, um zukünftige Fernlernansätze zu optimieren, aber auch diejenigen, die für die traditionelle Bildung spezifisch sind. Das Umdenken der Bildung ist zu einem der wichtigsten gegenwärtigen Ziele geworden, da Bildung tiefgreifende, langfristige Auswirkungen auf alle anderen Bereiche der Gesellschaft hat.

\section{Introduction}

The 2019-2020 school year had a quite special course of events in Romania.The activities scheduled for the second semester of this school year (especially from March until June 2020) have been strongly altered by the pandemic caused by coronavirus, declared by the WHO in early March 2020. As in other countries affected by this situation, in Romania all educational institutions were closed, and the activities that the students carried out in a formal context were further carried out from home, through technology, in the online version, with various changes and adaptations needed in this context. This new situation characterized in Romania mainly the urban areas, where the access to technology is easier, but also the final classes, which were to take the graduation exams.
Taking into consideration the fact that this situation may be prolonged indefinitely due to the contagion of Covid-19 infection and may lead to major changes in the subsequent implementation of all educational activities, as well as the fact that the measures described above were taken in a very short time, without any preparation of all factors affected by these changes, we considered appropriate to investigate the opinions of a group of middle school students $(\mathrm{N}=19)$ regarding this unusual period. The three months in which the students carried out school activities in the online version represent a long time for these teenagers, who move from one school cycle to another and undergo a unique period in their development. As mentioned by the Romanian Academy (2020), secondary 
school stage is the stage of strengthening general culture and it is located between the first steps of literacy and learning basic operations in the first years of school and the specialization that starts with the entrance to high school. The effects that all these last-minute changes have on middle school students, from a social, psychological and academic point of view, must be addressed so that the negative impact is reduced as much as possible.

The social distancing measures imposed in this context have affected the entire population, especially vulnerable groups such as children. Thus, we aimed to identify the students' point of view on how they carried out school activities in the online version, with everything that this approach involved, the way in which the assessment was carried out, their opinions on the results they achieved during this period, and their wishes and projections for the next school year. The investigated group consisted of middle school students, in their last year of this cycle of education $\left(8^{\text {th }}\right.$ grade $)$ from a school located in the urban area. These students were the first who returned to school after the closure in order to taketheir final exams (in Romania $8^{\text {th }}$ graders have to pass the National Exam in order to get to high school; the exams consist in written tests at mother tongue and mathematics). These exams took place under special conditions, imposed by the coronavirus epidemic. In this context, we asked students to describe their feelings and opinions regarding the assessment in special context with a lot of new rules.

This study shows that students are one of the groups significantly affected by this pandemic, and their feelings and thoughts about the situation they experienced are easily overlooked by decision makers. The social, psychological and academic effects that this period had on adolescents, but also on other students should be seriously taken into consideration. The transition to online education due to the pandemic caused by the coronavirus has been chaotic, insufficiently organized, and its previous context and longterm consequences must be carefully addressed in various future studies dedicated to this topic.

\section{Theoretical foundation}

Over time, all educational systems have undergone numerous transformations, visible in the roles and functions of institutions involved in education and due to constant attempts to adapt to changes imposed by the evolution of society and its needs. The differences between educational systems are not only noticeable over time, but also between different countries, in the context of the same historical interval. These contrasts are due to the different cultural background, the political, religious system, philosophical and pedagogical influences, which determine the emergence and promotion of different ideologies. The literature that studied until now these changes in the educational systems emphasizes the importance of their open and flexible nature; it is necessary for the educational system to be able to adapt to the evolution of society (Chiş, 2005). Ensuring the effectiveness of an educational system, its modelling to the specifics of the society in a certain period, represents a complicated, provocative approach, because it is dependent on a large number of factors. In the first months of the year 2020 the transformation of education systems has been largely driven by the pandemic caused by coronavirus. Thus, the transition from face-toface activities to online, digital education took place and everything that characterizes distance learning was used, as a result of the closure of many schools and the suspension of direct educational activities (Williamson, Eynon \&Potter, 2020). Thus, a new distinct perspective of pedagogy appeared at the beginning of the year 2020 . Distance learning or online education does not represent something new in the field of pedagogy, but the importance granted to them in the curriculum design is.

The educational system in Romania is organized hierarchically, corresponding to the Comenian organization, by classes and lessons. The educational activities are carried out both in traditional and modern ways (in the classroom, using different didactic strategies, starting with the well-known whiteboard until the modern interactive board and digital devices, depending on the equipment existing in each classroom) (Basilaia \& Kvavadze, 2020). Within this context, students have the duty to attend classes daily, based on a fixed weekly schedule. The study program and curriculum are common, mandatory elements that include standard requirements, valid for all students. In the second semester of the 2019 2020 school year, the transition to exclusive online education was made in the Romanian educational system. Starting with March 11, 2020, all schools were closed and the Ministry of Education recommended conducting support courses for students, assisted by technology. The suspension of face-to-face educational activities was subsequently extended until the end of the school year, in June 2020. Only 8th and 12th grade students returned to school after the end of the school year (June-July 2020) in order to take their graduation exams. These assessments were carried out under special conditions in order to comply with all measures required by the authorities to prevent the spread of the new coronavirus infection. Thus, there has been a forced decentralization of education, further conducted as a form of technology-mediated homeschooling (Williamson, Eynon \&Potter, 2020). These transformations did not take place only in the Romanian education system, but in most countries of the world, and, according to UNESCO (2020), affected over $60 \%$ of the students worldwide.

The transition to on-line activities determined a decrease in the allocated time for each activity (classes of maximum 40 minutes), so that the time spent by students in front of the screens does not have major negative effects on their health. Also, the access of students and teachers to the 
internet and computer, tablet or smartphone has become essential, and the limitations in access to education have been accentuated in the case of students coming from disadvantaged backgrounds or those with various disabilities. Significant difficulties were also noted in this respect by young children (pre-schoolers and young schoolchildren), who became dependent on adults for access to educational content and processing it. Regarding the participation of students in online courses, it should be noted that this was variable, without reaching $100 \%$ participation.

The changes made in the educational system in the context of the Covid-19 pandemic had the role of protecting the population and preventing and limiting the spread of infection with this virus, but also the role of continuing the educational process in order not to freeze the school year. In this period characterized by the transformation of education from traditional to online format in just a few days, many schools have benefited from the support of companies such as Microsoft, Google, Zoom or Amazon, which have rapidly expanded their educational services and offered free access for conducting online educational activities (Basilaia \& Kvavadze, 2020; Williamson, Eynon \&Potter, 2020). Also, in order to carry out the educational process as efficiently as possible after the closure of schools and the suspension of courses, UNESCO (2020) issued 10 recommendations, which address the main aspects involved in the transition to online education: selecting solutions according to existing availability, ensuring learning and access to learning for all categories of learners, protecting privacy and data security, building networks / communities to prevent any difficulties that students may face, planning distance learning, training and supporting teachers and parents for using digital technologies, avoiding overloading students through the use of all means available to them, limiting the number of applications and platforms used, making regulations for distance learning, getting direct feedback from students, minimal involvement of parents in the assessment process, adjust the time allocated to online teaching activities, creating communities to support students to overcome certain learning difficulties.

On the other hand, UNESCO (2020) draws attention to the adverse effects of school closures, which affect mainly students, especially the vulnerable and marginalized, and their families. The negative consequences refer mainly to the field of education, but also to other aspects of students' lives, namely: interruption or reduction of learning and development opportunities; poor nutrition; confusion, stress and frustration for teachers; the inability of parents to support students in achieving online education; challenges in conducting optimal online education from the technical point of view; difficulties for working parents in caring for their children (children spend a lot of time alone, which can lead to deviant behaviors); increasing the school dropout rate; increased cases of violence against minors and exploitation of children; social isolation of children and adolescents; difficulties in assessing students.

Other influential international organizations that have tried to facilitate online education and support states affected by the epidemic are the World Bank and the OECD. The latter described the epidemic period as a crisis of human capital development, and the pandemic as an opportunity to experiment new educational models and new ways of using face-to-face learning activities (OECD, 2020). Conducting online activities that involve formation and training of different skills, which require demonstrations, direct models of action, repeated exercises, directed, supervised corrections were one of the major challenges of achieving education in this manner.

In the literature we find references to the need of preparing countries regarding education in a context of pandemic. Jester, Uyeki and Jernigan (2018) discuss about preparing states to respond to a pandemic starting from the situation of pandemic that took place in 1918. Although there is currently increased capacity for prevention, monitoring, diagnosis and treatment, health and governance systems around the world are insufficiently prepared for the impact of a pandemic. Even if children are not a category severely affected by the coronavirus infection, they can become a source of its transmission, which was one of the main reasons for closing schools in most countries of the world (Abdulamir \&Hafidh, 2020).

Other studies show that school closure for a long period can have significant negative effects on students' physical and mental health. The existing organized structure in the case of face-to-face educational activities involves opportunities to make physical effort, reduce the amount of daily consumed calories, reduce the time spent in front of the screens and adjust the sleep-wake schedule (Brazendale et al., 2017). In the case of isolation of adolescents at home, all these aspects can become problematic and can lead to serious health problems. Another particularly important, but often neglected, issue is the psychological impact of school closure on children and adolescents. Prolonged isolation causes frustration, boredom, fear, irrational thoughts, lack of face-to-face contact with other colleagues, friends and teachers, lack of personal space at home, financial difficulties of the family (Wang et. al., 2020). Thus, the psychologycal impact of the quarantine is wide-ranging, subsantial and can be long-lasting (Brooks et. al, 2020).

Another perspective refers to the digital competencies required by online education (Williamson et al., 2020). It must be borne in mind that the current generations of students are the generations of young people who grow up surrounded by digital technology, the digital natives (Prensky, 2001). Obviously, there is a gap between the degree of exposure to technology and the ability of these students to use it in a rational way, beneficial to their social and professional development and integration, as well as 
between the opportunities and risks involved in using technology. However, online education can be a response for these generations to the need to adapt education to the evolution of society. Thus, the locus of control of pedagogy must be rethought, restored, taking into account the attraction of current generations of young people to new technologies and involving not only educators, but the entire community (Selwyn et. al., 2020).

\section{Research methodology}

Within our exploratory research we aimed to gain insightful, in-depth information. The research method selected for this study was a questionnaire-based survey. The main reasons for selecting this approach were: rapid administration, adjusted to the current specific situation (taking into consideration that face-to-face meetings are limited because of the pandemic), possibility of ensuring anonymity for subjects, fact that facilitates obtaining honest answers. The questionnaire included 20 items, 18 of them were open-ended questions and the other two required demographic information.

The present survey aimed to answer the following research questions:

- What do students think about online education during Covid Pandemic in Romania?

- How did their schooling process take place during this special period?

We set out to investigate the opinions of a group of eighth graders through open-ended questions, because students are the main beneficiaries of the educational act and in the attempt of optimizing educational processes opinions of all involved actors are very important. Education must respond to their needs. Even when conducted online and under special conditions the main goals of all educational actions refer to the well-being, health and happiness of every child (Walker, 2018). We considered eighth graders mature enough to provide valid, worthwhile opinions regarding the education process during the Covid Pandemic and their experience regarding their schooling during this period. Another reason that supports our option for questioning students refers to the fact that few studies have focused before on students satisfaction with online education, particularly in the situation of transition from traditional approaches to online teaching and learning (Smart \& Cappel, 2006).

The questionnaire was developed and completed online. The participants ( $\mathrm{N}=19,11$ girls and 8 boys) were eighth graders from George Cosbuc School, Cluj-Napoca, Romania, learning in the same class. The average age of these students was 14 years old. They all live in the city and have good access to internet.

In Romania, the eighth graders must take the National Exams as they finish the middle/lower-secondary education (gymnasium). In the 2019-2020 school year the eighth grade students were the first students, who returned to school in order to take their final exams. These assessments were held in Romania in special conditions, imposed by the Covid Pandemic. All students involved in the present study passed these exams and will begin high school $\left(9^{\text {th }}\right.$ grade $)$ in autumn 2020.

The data collected in July 2020 using the mentioned questionnaire focused on the following aspects:

- students' thoughts and feelings regarding the school closure

- $\quad$ students' opinions regarding online classes

- students' opinions regarding advantages and disadvantages of online schooling

- students' opinions regarding their educational achievement during the pandemic

- students' opinions regarding the conduct of their final exams

- students' wishes and expectations for the next school year.

The questionnaire included a relative high number of questions. Although this aspect may discourage respondents, we chose this structure in order to find out as much relevant information as possible. We chose to include open-ended questions since we aimed to investigate opinions, thoughts and feelings. Thus, the respondents had the freedom to express themselves in relation to the investigated topic as they wished. The obtained answers were categorized and qualitatively analysed.

\section{Results}

We were happy to see that all students answered all questions of each questionnaire and returned the file with the answers to the researcher. The results were gathered around the main aspects aimed by the questionnaire and will be presented for each established category.

\subsection{Students' thoughts and feelings regarding the school closure}

At the beginning the students thought that school closure is a good, interesting, entertaining idea and felt happy to stay at home. They viewed this time as a break or vacation, were happy that they will no longer have to do so much homework, get rid of traditional tests, sleep longer in the mornings and will have the possibility to eat healthier and have their meals at proper times. They hoped to feel more comfortable to learn from home. They thought online schooling is an interesting method and felt happy to have more time to focus their learning on the exam subjects, to study in their own rhythm, to take notes as they wished, to make their own daily schedule, since there were less classes online compared to the scheduleat school. But, as the days passed and the school suspension has been prolonged, they started to feel sad, exhausted, disappointed and realized that online schooling is not beneficial for them. Their wish for 
attending traditional school and meeting their friends was very strong. They started to miss a lot of aspects characteristic to traditional, face-to-face schooling. They also discovered that online education involves certain difficulties and remarked the advantages of face-to-face education for their academic progress.

\subsection{Students' opinion regarding online classes}

Students mentioned using the following systems and applications for digital learning: Microsoft Teams, Google Classroom, Discord, Zoom, Skype, Google Meet, 8x8 VideoMeetings, WhatsApp, Edmodo. Being already familiar with Microsoft Office helped students in using this platforms and applications. They got used to them easily, along the way, using the instructions available on each program and sometimes asking colleagues, parents or teachers to clarify certain aspects.

Some students mentioned that it was hard at the beginning to organize themselves so that they did not miss any meeting or homework. Other difficulties that students faced during online schooling referred to: problems in sending materials to the teacher, finding worksheets and loading them on the platform after being solved and not knowing if the teacher received them (teachers started confirming receiving homework files after students asked them); receiving less information compared to the classes at school and being hard to access and process it; difficulties in getting used to the long time spent before the monitor and being tempted to do something else and not to concentrate in class; feeling unsure and tired because of the daily schedule since some meetings were announced, cancelled or postponed only few minutes before. Students also mentioned having problems with the internet connection, but they also mentioned this as a problem of some teachers as well. They observed that teachers were also unfamiliar in using online teaching. So, their first classes were more attempts in establishing a good connection to these applications and getting used to this new way of teaching and learning and communicating with their teachers. At the beginning students only had classes in a few subjects, but along the way, they met all their teachers and had classes in each subject. Students enjoyed that at the beginning they made lots of revisions lessons, so that this was not so difficult for them and could get used to the new way of schooling.

Although, online classes were less demanding (less homework or exercises), looser, the rhythm less intense, the teachers more understanding than at school, no student liked online schooling more than traditional education. They said they didn't understand the content transmitted by teacher, at school being simpler to keep up with the teachers explanations and that in online context there has been a lot of dictation. They felt the lack of explanations in going through some materials and making exercises in class, even though teachers posted a lot of files in order to counterbalance the lack of direct communication. The atmosphere in online classes is more silent and relaxed than the one at school, but less accessible for understanding the information because one has to deal alone with everything (information + procedures required by the platform).

Students also remarked that online education is not suitable for all school subjects, more specific not all subjects fit to the online learning platforms. They mentioned some relevant examples regarding this aspect: it takes a lot to write certain equations in Word at Mathematics or Chemistry; Discord program is not suitable for Mathematics; teaching geometric bodies in space is difficult to do online; digital mind maps at Chemistry are hard to complete. Students think that subjects related to hard sciences are difficult to be taught online, because they need a lot of explanations, but subjects that are related to the humanistic field, such as foreign languages, for example, are easier to be taught online, because teachers and students can benefit from using a lot of online materials, such as films, music etc. Students also identified the lack of practical aspects during online classes in certain subjects (for example not being able to see an experiment relevant for certain contents).

\subsection{Students' opinion regarding advantages and disadvantages of online schooling}

Students were able to identify a series of advantages and disadvantages of online schooling, starting of course from their own experience. Although all students specified that they prefer traditional, face-to-face education, at school, they were able to be objective enough to name the positive and negative aspects of online education.

The advantages of online education mentioned by students are:

- each student works in his own rhythm and can establish his own working style while spending a long time at home

- $\quad$ students are more comfortable at home (not having to get dressed for school, having the possibility to sleep and eat properly, spending more time with their family)

- students are safe at home and not exposed to the virus

- students can retrieve certain aspects in different subjects in order to get better and to develop their knowledge.

Regarding the disadvantages, students mentioned the following aspects:

- it is hard for students to have the same attitude during online classes compared to traditional schooling

- students encounter problems in understanding the new information and the requirements of teachers

- students are more tempted in not being focused on class

- students encounter technical difficulties 
- teachers don't have control over their students during classes

- it is difficult for teachers to involve students during class

- lack of social contact (student-student, studentteacher)

- students don't have equal chances in attending online education

- students learn less and their learning motivation decreases.

4.4. Students' opinion regarding their educational achievement during the pandemic

Regarding the assessment conducted during the period of online schooling the students mentioned that they felt it less demanding compared to what happens at school. They got grades for their answers during the online classes, for the worksheets they had to send to teachers after completing them individually and independent in a certain time, for projects and essays. They also got tests during the online classes in some cases. They were assessed for all subjects and for all their activity and work during this special period, but they felt that online schooling affected not only their grades, but also their knowledge and achievements. Although students considered that the grades were obtained easier and were better compared to the ones in school, they felt that at school it is more efficient to learn new things.

During the quarantine students had more time for individual study, focusing on the difficult aspects of the subjects and could improve their work style. Although, in an online context a lot of students felt unsure regarding the procedures they used to solve certain tasks, and sometimes they missed the teachers feed-back. They expected feedback related not only to the final result, but also regarding the steps they used in order to solve certain requirements. Also, some students think they sometimes focused more on the procedures imposed by the online application or platform they used and less on the subject or content they had to learn.

\subsection{Students' opinion regarding the conduct of their final exams}

The final exams in Romania were conducted in a special manner this year. Students had to wear masks during the entire session and had to pass the epidemiological triage. The students involved in the present study viewed this as an interesting experience, but not necessary in a good way. Only one student was comfortable from the beginning with all this measures. The rest felt disappointed, stressed, scared due to the many new rules involved in the exam situation. Some students mentioned that wearing a mask during the exam was weird and uncomfortable for them. Others said that when they found out they will have to wear a mask during the entire exam they started preparing at home for this aspect. They wore a mask and solved exercises at home in order to get used to concentrate on the content and not on wearing the mask, until they could do this for two hours (the time for each exam session). Except this training in wearing a mask they used the quarantine time to study more for their exams, to get better at the aspects they did not master very well.

Regarding the content they had to learn for the exams, they felt lucky, since some themes were eliminated from the exam curriculum due to the school closure.

When they found out that they will have to go to school to sustain their exams some students felt happy for having the possibility to return to school and see their colleagues, even from a distance.

\subsection{Students' wishes and expectations for the next school year}

All students wish to go to school next school year, even if this implies respecting strict sanitary rules and wearing a mask. They mentioned aspects they missed a lot in the last months, like sitting in the bench, meeting their colleagues or writing exercises on the blackboard. All students think they can get used to the new rules imposed in the Covid-19 Pandemic situation and hope that the number of sick people will decrease, so that they can go back to school at least for part of the classes and in small groups. Their opinion is that they can learn better and easier at school. They mentioned that during the time spent at home due to the quarantine, they realized how important school is for them and how much they enjoy going to school to learn new things and meeting their colleagues and teachers in person. They affirmed it is valuable to see your friends and to be able to meet your new colleagues and establish new friendships with them.

If they had to continue next year with online schooling, the students proposed the following changes in order to optimize online education: establishing a fix schedule for their classes with established breaks, since their experience was pretty chaotic from this point of view; introducing an online school regulation; giving tablets to all students; conducting all classes for all subjects using only one platform or application suitable to all subjects; establishing rules regarding the time spent by students in front of the screen and the time spent by them preparing their homework (not overloading students with homework); supporting students with drafts of the studied content that students can go through before the video conference with teachers; working more on worksheets with teachers during the video conference. The questioned students propose online schooling as an addition to the traditional schooling, used only in special situations and for short periods of time.

\section{Discussions and Conclusions}

Taking into consideration the results presented above we can conclude that authorities need to focus their activity on a safe return to school for students. Even if the students involved in this study do not represent a significant group 
for the approached topic, we can affirm that their opinions are worthy of consideration in order to optimize the educational process for the specific needs of teenagers. Their strong wish to return to school is complementary to the specific of their development stage. Teenagers go through main cognitive, social and physical changes, they are eager for knowledge, curious, trying to develop their independence and identity. Having only online interactions with their peers for a longer time can impact their development and their achievements of all kinds. Missing out on social connections and networks is a difficulty encountered by all students that suffered from school closure in the last months and this impacts their educational achievements as well.

Regarding students opinions about online schooling, we can observe that what students expressed is consonant with the vision of the Romanian Academy (2020), namely that online education cannot constitute a goal in itself for the Romanian world, but it must be an effective means of completing and supplementing - in special cases, when absolutely necessary - what direct education, in classrooms, laboratories, amphitheatres, etc., cannot achieve.

During the period of school suspension and online education, students gained skills that help them use diverse instruments for knowledge and communication. Although the switch to online education was chaotic in practice, the skills students gained can be used in the future for special situations like missing out school. The school has the responsibility to develop students' disposition and capacity to learn in multiple environments, using various sources of information (Albulescu, 2003, p. 176). The situation created by the Covid-19 Pandemic demonstrated that the human capacity to adjust rapid to new, unknown situations should be one of the most important educational objective.

We conclude that education, and especially online education must be a matter of concern for all actors involved in the educational process. Guidance and support should be provided, in the form of different counseling programs and training sessions, to students of any age in order to encounter such situations as the present one with great capacity of adjustment, but also to teachers, parents and other actors involved directly in all educational actions. So far online education has demonstrated to be challenging, with several facets, both positive and negative ones. Its quality needs to be profound approached in future studies.

Our study has some limitations, regarding the sample of involved participants, their unilateral perspective and the few research methods used in the current situation. Another limit refers to the specific of the qualitative approach, namely the reduced validity of the obtained results. Further studies can analyze more profoundly students' opinions related to online education, involving a larger sample of participants, but also more diverse research methods and instruments. Another aspect that can be approached by future studies refers to the long-term effects of the transition to online education due to the Pandemic.

\section{Appendix}

\section{Questionnaire regarding students' opinions about online schooling during Covid-19 Pandemic}

Through this questionnaire we wish to found out your opinion regarding your experience with online schooling during the Covid-19 Pandemic and the changes that appeared in this period (school closure, on-line classes and assessment etc.). The questionnaire is anonymous and will only be used within a pedagogical study. Feel free to share your thoughts, feelings and opinions, mention anything you find relevant regarding your experience during this special period.

1. Which was your first thought when you found out about school closure?

2. Which were the educational platforms/applications you used in this period for online schooling?

3. How did you learn to use these platforms/applications?

4. What did you like about online schooling?

5. Did you encounter any difficulties? If yes, how did you overtake them?

6. How were the first online classes? How do you find this way of teaching and learning in comparison with the traditional one?

7. How did the assessment process take place?

8. Do you think your academic results would have been different if the schools would not have closed and you would have gone to school as usual?

9. Were there any changes that appeared in online classes? What did these changes refer to?

10. Was it easier or harder to go through the contents of the subjects online? Why?

11. Do you think that online learning platforms and applications are suitable for all school subjects? Did you note any differences regarding this aspect?

12. Which are, in your opinion, the main advantages of online education?

13. What about the disadvantages?

14. Would you change something at online education? What and why?

15. Would you prefer to go to school next semester, even if this means that you are more exposed to the illness and you have to respect a lot of new strict regulations or do you want to continue online schooling? Why?

16. Do you think that online schooling has affected your grades? Why?

17. How did you find the final exams conducted in 
special conditions? (Describe how you felt when you found out that you will take the exam under special regulations, how did you prepare for the exams, how did the exam take place and anything more you find relevant).

18. What are your wishes for the new school year?

19. Gender $\mathrm{M} \square \quad \mathrm{F} \square$

20. Age

\section{Authors note:}

Alexandra Ioana Oltean is Assistant Professor at the Department of Educational Sciences, Faculty of Psychology and Educational Sciences, Babeş-Bolyai University, Romania. Her Ph.D. is in Educational Sciences. Her research is in the field of preschool education, teacher training and students' counselling.

\section{References}

Abdulamir, A. S., \& Hafidh, R.R. (2020). The Possible Immunological Pathways for the Variable Immunopathogenesis of COVID-19 Infections among Healthy Adults, Elderly and Children. Electronic Journal of General Medicine, 17(4), retrieved from https://www.ejgm.co.uk/download/the-possibleimmunological-pathways-for-the-variableimmunopathogenesis-of-covid-19-infections-among7850.pdf.

Albulescu, I. (2003). Educația și mass-media. ClujNapoca: Editura Dacia

Basilaia, G., \& Kvavadze, D. (2020). Transition to Online Education in Schools during a SARS-CoV-2 Coronavirus (COVID-19) Pandemic in Georgia. Pedagogical Research, 5(4), retrieved from https://www.researchgate.net/publication/340560537 _Transition_to_Online_Education_in_Schools_durin g_a_SARS-CoV-2_Coronavirus_COVID19_Pandemic_in_Georgia.

Brazendale, K., et. al. (2017). Understanding differences between summer vs. school obesogenic behaviors of children: The structured days hypothesis. International Journal of Behavioral Nutrition and Physical Activity, 14.(1), retrieved from https://www.researchgate.net/publication/318713807 _Understanding_differences_between_summer_vs_sc hool_obesogenic_behaviors_of_children_The_structu red_days_hypothesis.

Brooks, S. K., Webster, R. K., Smith, L. E., Woodland, L., Wessely, S., Greenberg, N., \& Rubin, G.J., (2020). The psychological impact of quarantine and how to reduce it: rapid review of the evidence. The Lancet, retrieved from https://www.thelancet.com/action/showPdf?pii=S014 0-6736\%2820\%2930460-8.
Chiș, V. (2005). Pedagogia contemporană - Pedagogia pentru competențe. Cluj-Napoca: Casa Cărții de Știință.

Jester, B., Uyeki, T., \& Jernigan, D. (2018). Readiness for Responding to a Severe Pandemic 100 Years After 1918. American Journal of Epidemiology. 187(12), retrieved

from https://academic.oup.com/aje/article/187/12/2596/506 8408

Prensky, M. (2011). Digital Natives, Digital Immigrants. On the Horizon (MCB University Press, Vol. 9 No. 5, retrieved

from https://marcprensky.com/writing/Prensky\%20\%20Digital\%20Natives,\%20Digital\%20Immigrants \%20-\%20Part1.pdf

Selwyn, N., T. Hillman, R. Eynon, G. Ferreira, J. Knox, F. MacGilchrist, \& J. M. Sancho-Gil. 2020. What's Next for Ed-Tech? Critical Hopes and Concerns for the 2020s'. Learning, Media and Technology, 45 (1): 1-6.

Smart, K.L. \& Cappel, J.J. (2006). Students' Perceptions of Online Learning: A Comparative Study. Journal of Information Technology Education, 5, 201-219. Retrieved

from https://www.learntechlib.org/p/101752/.

Walker, T.D. (2018). Să predăm ca în Finlanda. 33 de strategii simple pentru lecții pline de bună-dispoziție. Bucuresti: Editura Trei.

Wang, G., Zhang, Y., Zhao, J., Zhang, J., Jiang, F., (2020). Mitigate the effects of home confinement on children during the COVID-19 outbreak. The Lancet. VOLUME 395, ISSUE 10228, retrieved from https://www.thelancet.com/journals/lancet/article/PII S0140-6736(20)30547-X/fulltext.

Williamson, B., Eynon, R., \&Potter, J. (2020). Pandemic politics, pedagogies and practices: digital technologies and distance education during the coronavirus emergency. Learning, Media and Technology, 45:2, 107-114, retrieved from https://www.tandfonline.com/doi/full/10.1080/17439 884.2020.1761641.

*** Academia Română (Romanian Academy) (2020). Punct de vedere privind educația on-line și educația în clasă. (Point of view regarding online education and education in the clasroom). Retrieved from https://acad.ro/mediaAR/pctVedereAR/2020/d0728Punct_de_vedere_Educatia_online_si_educatia_in_clasa.pdf at03.08.2020).

(Accessed

***Academia Română (Romanian Academy) (2020). Punct de vedere privind noul Plan-Cadru pentru învățământul gimnazial din România. (Point of view regarding the new Framework Plan for secondary education). Retrieved from https://acad.ro/mediaAR/pctVedereAR/2020/d0810PunctVedere- 
PlanulCadruInvatamantGimnazial.pdf(Accessed at02.09.2020).

***Ministerul Educației și Cercetării (Romanian Ministry of Education and Research) (2020) Măsuri luate de Ministerul Educației și Cercetării ca urmare a Hotărârii nr. 6 a Comitetului Național pentru Situații Speciale de Urgență (Measures improved by the Ministry of Education and Reseach as a result of Decision no. 6 of the National Committee for Special Emergency Situations) retrieved from https://www.edu.ro/m\%C4\%83suri-luate-deministerul-educa\%C8\%9Biei-\%C8\%99i-

cercet $\%$ C4\% 83rii-ca-urmare-

hot $\%$ C4\%83r\%C3\%A2rii-nr-6-consiliuluina\%C8\%9Bional (Accessed at 15.07.2020).

***OECD (2020) Education Responses to Covid-19: Embracing Digital Learning and Online Collaboration, retrieved from https://read.oecdilibrary.org/view/?ref=120_120544-

8ksud7oaj2\&Title=Education\%20responses\%20to $\% 20$ covid-

19:\%20\%20Embracing\%20digital\%20learning\%20an $\mathrm{d} \% 20$ online \%20 collaboration

(Accessed at02.06.2020).

***The World Bank (2020) Grupul Băncii Mondiale: 100 de țări beneficiază de sprijin ca reacție la COVID-19
(Coronavirus) (The World Bank Group: 100 countries benefit from support as reaction to COVID-19 (Coronavirus), retrieved from https://www.worldbank.org/ro/news/pressrelease/2020/05/19/world-bank-group-100-countriesget-support-in-response-to-covid-19-coronavirus (Accessed at02.09.2020).

***UNESCO (2020) COVID-19 Impact on Education, retrieved from https://en.unesco.org/covid19/educationresponse (Accessed at 10.07.2020).

***UNESCO (2020) COVID-19: 10 Recommendations to plan distance learning solutions, retrieved from https://en.unesco.org/news/covid-19-10recommendations-plan-distance-learning-solutions (Accessed at22.08.2020).

***UNESCO (2020) Adverse consequences of school closures, retrieved from https://en.unesco.org/covid19/educationresponse/cons equences (Accessed at22.08.2020).

***World Health Organization (2020) WHO DirectorGeneral's opening remarks at the media briefing on COVID-19 - 11 March 2020, retrieved from https://www.who.int/dg/speeches/detail/who-directorgeneral-s-opening-remarks-at-the-media-briefing-oncovid-19---11-march-2020 (Accessedat 02.07.2020). 